\title{
Systemic Sclerosis-associated Pulmonary Arterial Hypertension
}

\author{
Jérôme Le Pavec1,2, Marc Humbert², Luc Mouthon³, and Paul M. Hassoun' \\ ${ }^{1}$ Division of Pulmonary and Critical Care Medicine, Johns Hopkins University School of Medicine, Baltimore, Maryland; ${ }^{2}$ Université Paris-Sud 11, \\ Service de Pneumologie et Réanimation Respiratoire, Hôpital Antoine Béclère, Assistance Publique Hôpitaux de Paris, Clamart, France; and the \\ Université Paris-Descartes, Department of Internal Medicine, Hôpital Cochin, Assistance Publique Hôpitaux de Paris, Paris, France
}

\begin{abstract}
Pulmonary arterial hypertension (PAH) is a devastating vascular complication of a number of connective tissue diseases, including systemic sclerosis (SSc), where it has a dramatic impact on the clinical course and overall survival and is the single most common cause of death in patients afflicted with this syndrome. Although remarkable advances have been achieved in elucidating the pathogenesis of $\mathrm{PAH}$ over the past 2 decades, leading to the development of diseasetargeted therapies for the idiopathic form of this condition (IPAH), the response to therapy is suboptimal in SSc-related PAH (SSc-PAH), and survival remains very poor. Factors accounting for striking clinical and prognostic differences between these two syndromes are unclear but may include a more pronounced autoimmune, cellular, and inflammatory response, and a higher prevalence of comorbidities in SSc-PAH, including cardiac and pulmonary venous and parenchymal involvement. Furthermore, currently available markers of disease severity and clinical tools to assess response to therapy, which may be reliable in IPAH, are either limited or lacking in SSc-PAH. Thus, a more focused approach, including a better understanding of the pathogenesis and genetic factors underlying the development of SSc-PAH, a search for more specific and reliable tools to adequately assess functional impairment and monitor therapy, as well as the design of novel targeted therapies, are all urgently required to alter the dismal course of this syndrome.
\end{abstract}

Keywords: scleroderma; pulmonary hypertension; prognostic factors

Systemic sclerosis (SSc) is a heterogeneous disorder characterized by dysfunction of the endothelium, dysregulation of fibroblasts resulting in excessive production of collagen, and abnormalities of the immune system (1). These processes lead to progressive fibrosis of the skin and internal organs resulting in premature organ failure and death. Although the cause of SSc is unknown, genetic and environmental factors are believed to contribute to host susceptibility (2). Whether presenting in the limited or diffuse form, SSc is a systemic disease with the potential for multiple organ involvement, including the gastrointestinal, cardiac, renal, and pulmonary systems (1). However, SSc-related pulmonary arterial hypertension (SSc-PAH) has emerged as a leading cause of mortality (3). Although remarkable advances have been achieved in elucidating the pathogenesis of PAH over the past 2 decades, leading to the development

(Received in original form September 3, 2009; accepted in final form February 24, 2010) Supported by National Institutes of Health grant NHLBI P50 award no. HL084946 (P.M.H.).

Correspondence and requests for reprints should be addressed to Paul $M$. Hassoun, M.D., Division of Pulmonary and Critical Care Medicine, Johns Hopkins University Department of Medicine, 1830 East Monument Street, Room 530 Baltimore, MD 21287. E-mail: phassoun@jhmi.edu

Am J Respir Crit Care Med Vol 181. pp 1285-1293, 2010

Originally Published in Press as DOI: 10.1164/rccm.200909-1331PP on March 1, 2010 Internet address: www.atsjournals.org of disease-targeted therapies for the idiopathic form of this condition (IPAH), the response to therapy is suboptimal in SSc$\mathrm{PAH}$ and survival remains very poor (4-6).

\section{SCOPE OF THE PROBLEM}

\section{Prevalence and Incidence}

In prospective studies using right heart catheterization (RHC) for diagnosis, the prevalence of SSc-PAH is between 7.8 and $12 \%(7,8)$. With an estimated U.S. prevalence of SSc of about 240 cases per million and a conservative PAH prevalence of $10 \%$ among these patients, the estimated overall prevalence of $\mathrm{SSc}-\mathrm{PAH}$ is around 24 individuals per million, which represents 5 to 10 times the number of patients affected by IPAH (9). In the French PAH registry, connective tissue disease (mainly represented by SSc) accounts for $15.3 \%$ of PAH cases (10). Probably because of a higher prevalence of SSc in the United States (11), the proportion of SSc-PAH is at least $30 \%$ of patients with $\mathrm{PAH}$, as indicated by one single large registry (12). In a recent prospective study, the estimated incidence of PAH among patients with SSc was 0.61 cases per 100 patient-years (13).

\section{Risk Factors}

Several clinical markers are associated with an increased risk of developing $\mathrm{PAH}$ in the setting of SSc, including limited skin involvement (14-17), disease duration greater than 10 years (15), late age of onset of SSc (14), severity (17) or duration (18) of Raynaud phenomenon, and reduced nailfold capillary density (15, 19). Several investigators have emphasized the pivotal role of an isolated reduction in diffusing capacity of carbon monoxide $\left(\mathrm{DL}_{\mathrm{CO}}\right)$ or a progressive decline of $\mathrm{DL}_{\mathrm{CO}}$ as an independent predictor for subsequent PAH $(14,17)$. Although the decrease in $\mathrm{DL}_{\mathrm{CO}}$ is likely the result of progressive pulmonary vascular remodeling over time, it is interesting to note that this alteration is significantly more pronounced in patients with SSc-PAH compared with patients with IPAH (4), perhaps suggesting more profound small-vessel remodeling in the former compared with the latter.

\section{Survival}

Compared with patients with IPAH, those with SSc-PAH are almost four times more likely to die from their disease (4). Moreover, outcomes in SSc-PAH remain worse than those in PAH associated with other connective tissue diseases (20). At a time of broader treatment availability, and despite substantial improvements in other PAH categories, 3-year survival remains less than $60 \%(4,5,8,20,21)$ (Figure 1). Markers of worse prognosis include male sex (20), late age at diagnosis (20), pericardial effusion (4), functional severity based on New York Heart Association functional class (20), right heart dysfunction $(8,22)$, and hyponatremia $(23)$. 


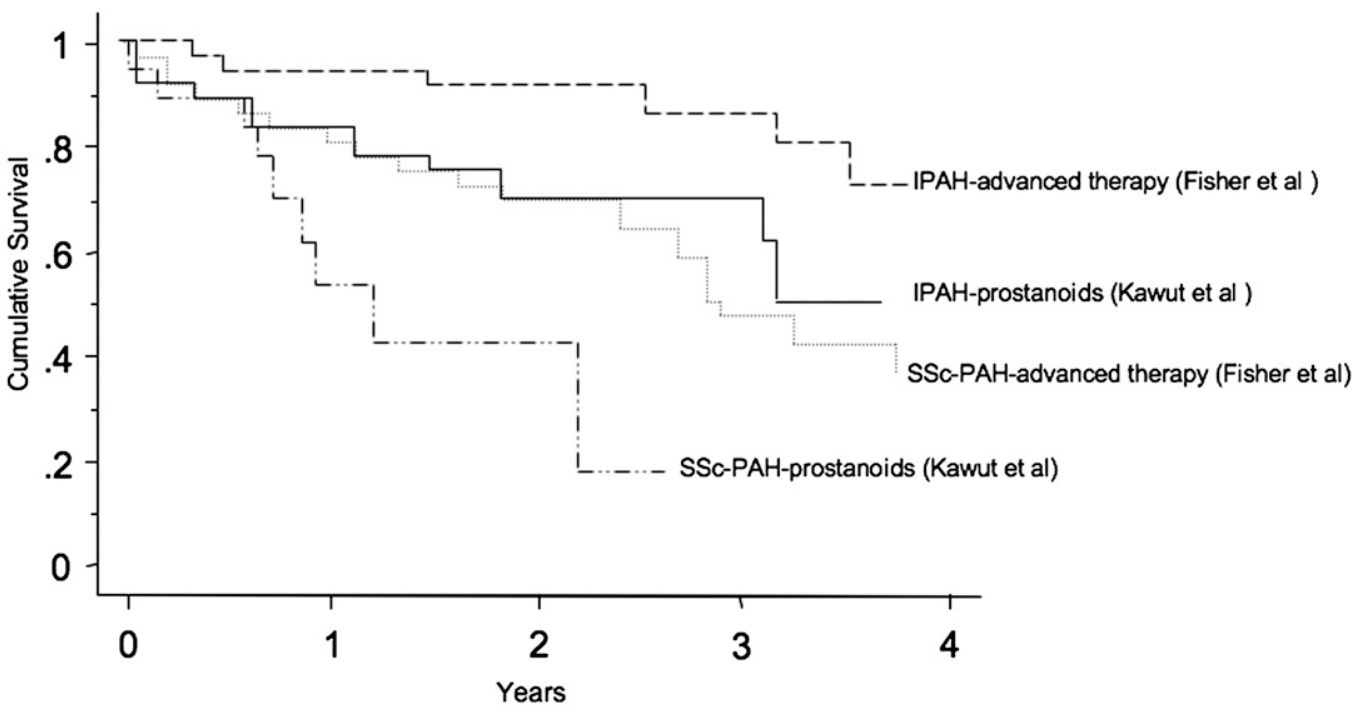

\begin{tabular}{|c|c|c|c|c|}
\hline Studies & \multicolumn{2}{|c|}{ Kawut et al 6} & \multicolumn{2}{|c|}{ Fisher et al ${ }^{4}$} \\
\hline Period of time & \multicolumn{2}{|c|}{$1997-2001$} & \multicolumn{2}{|c|}{$2000-2005$} \\
\hline Patients & $\begin{array}{l}\text { IPAH } \\
n=33\end{array}$ & $\begin{array}{c}\text { SSc-PAH } \\
n=22\end{array}$ & $\begin{array}{l}\text { IPAH } \\
n=41\end{array}$ & $\begin{array}{l}\text { SSc-PAH } \\
n=50\end{array}$ \\
\hline First line PAH therapy & \multicolumn{2}{|c|}{ Prostanoïds } & \multicolumn{2}{|c|}{$\begin{array}{l}\text { ERA, PDE5 inhibitors, or } \\
\text { prostanoïds according to guidelines }\end{array}$} \\
\hline NYHA FC III-IV, \% & \multicolumn{2}{|c|}{ - } & 77.5 & 64 \\
\hline mPAP, $\mathrm{mmHg}$ & $52 \pm 12$ & $48 \pm 10$ & $54 \pm 1.9$ & $47 \pm 1.5$ \\
\hline $\mathrm{Cl}$, L. $\min ^{-1} \cdot m^{-2}$ & $2.1 \pm 0.62$ & $2.2 \pm 0.54$ & $2.1 \pm 0.1$ & $2.2 \pm 0.1$ \\
\hline PVR, dyn.s.cm-5 & $918 \pm 433$ & $755 \pm 238$ & $941 \pm 88$ & $855 \pm 83$ \\
\hline
\end{tabular}

Figure 1. Kaplan-Meier analysis showing survival in patients with systemic sclerosis-related pulmonary arterial hypertension (SSc-PAH) and idiopathic pulmonary arterial hypertension (IPAH) treated with prostanoids (6) or advanced therapy (4). ERA = endothelin receptor antagonists; mPAP $=$ mean pulmonary arterial pressure; NYHA = New York Heart Association; PDE5 = phosphodiesterase 5; PVR = pulmonary vascular resistance.

\section{ROLE OF INFLAMMATION AND AUTOIMMUNITY}

Inflammation plays a significant role in IPAH and SSc-PAH (Figure 2). A subset of patients has circulating autoantibodies (e.g., antinuclear antibodies) and elevated levels of IL-1 and IL6 (24). However, it is likely that inflammatory pathways and autoimmunity are more pronounced in SSc-PAH, explaining clinical and prognosis differences between the two syndromes.

\section{Inflammatory Cells}

Macrophages, $\mathrm{T}$ and $\mathrm{B}$ lymphocytes, and dendritic cells are found around plexiform lesions (24). Levels of macrophage inflammatory protein- $1 \alpha$, IL-1 $\beta$ and IL-6, and P-selectin are increased in severe IPAH (24). Involvement of leukocytes, macrophages, and lymphocytes, initially described in the complex vascular lesions of IPAH (25), is also a prominent feature in PAH associated with connective tissue diseases (26).

\section{Vascular Changes in SSc and Evidence of Autoimmunity as a Central Component of Remodeling}

Vascular changes occur at an early stage in SSc and include apoptosis (27), endothelial cell (EC) activation with increased expression of cell adhesion molecules, inflammatory cell recruitment, a procoagulant state (28), intimal proliferation, and adventitial fibrosis leading to vessel obliteration. Endothelial injury is reflected by increased levels of soluble cell adhesion molecules, disturbances of angiogenesis as reflected by increased levels of circulating vascular endothelial growth factor $(29,30)$, and presence of angiostatic factors (30). Thus, the role of dysregulated angiogenesis in SSc-PAH, whether driven by the inflammatory process or other mechanisms, is a predominant feature of the disease and should be a focus of future studies as a potential target for therapy.

\section{Autoantibodies in SSc-PAH}

A role for autoimmunity is suggested by the presence of a number of autoantibodies in the serum of patients with SSc, including classic autoantibodies such as anti-centromere, antitopoisomerase 1, anti-RNA-polymerase III, anti-fibrillarin (U3 small nucleolar ribonucleoprotein), anti-Th/To, and anti- polymyositis/scleroderma, and more recently anti-fibrillarin 1 , antimatrix metalloproteinases 1-3, anti-platelet-derived growth factor (PDGF), anti- novel antigen-2 (nonsteroidal antiinflammatory drug-activated gene), anti-fibroblast, and anti-EC antibodies (AECA) (31). Antibodies have also been reported in SSc-PAH, including fibrin-bound tissue plasminogen activator in patients with limited cutaneous SSc, and in patients with IPAH with HLA-DQ7 antigen (32), and anti-topoisomerase II$\alpha$ antibodies, particularly in association with HLA-B35 antigen (33). Anti-EC antibodies can activate EC, induce the expression of adhesion molecules, and trigger apoptosis (34). In vitro, autoantibodies from patients with connective tissue diseases (anti-U1-ribonucleoprotein and anti-ds-DNA) can up-regulate adhesion molecules and histocompatibility complex class II molecules on human pulmonary arterial EC (35), suggesting that inflammation could lead to pulmonary proliferative vasculopathy.

Fibroblasts are found in the remodeled neointimal layer in both SSc-PAH and IPAH. Thus, the detection of anti-fibroblast antibodies in the serum of patients with SSc-PAH and IPAH (36) has significant pathogenic importance because these anti- 


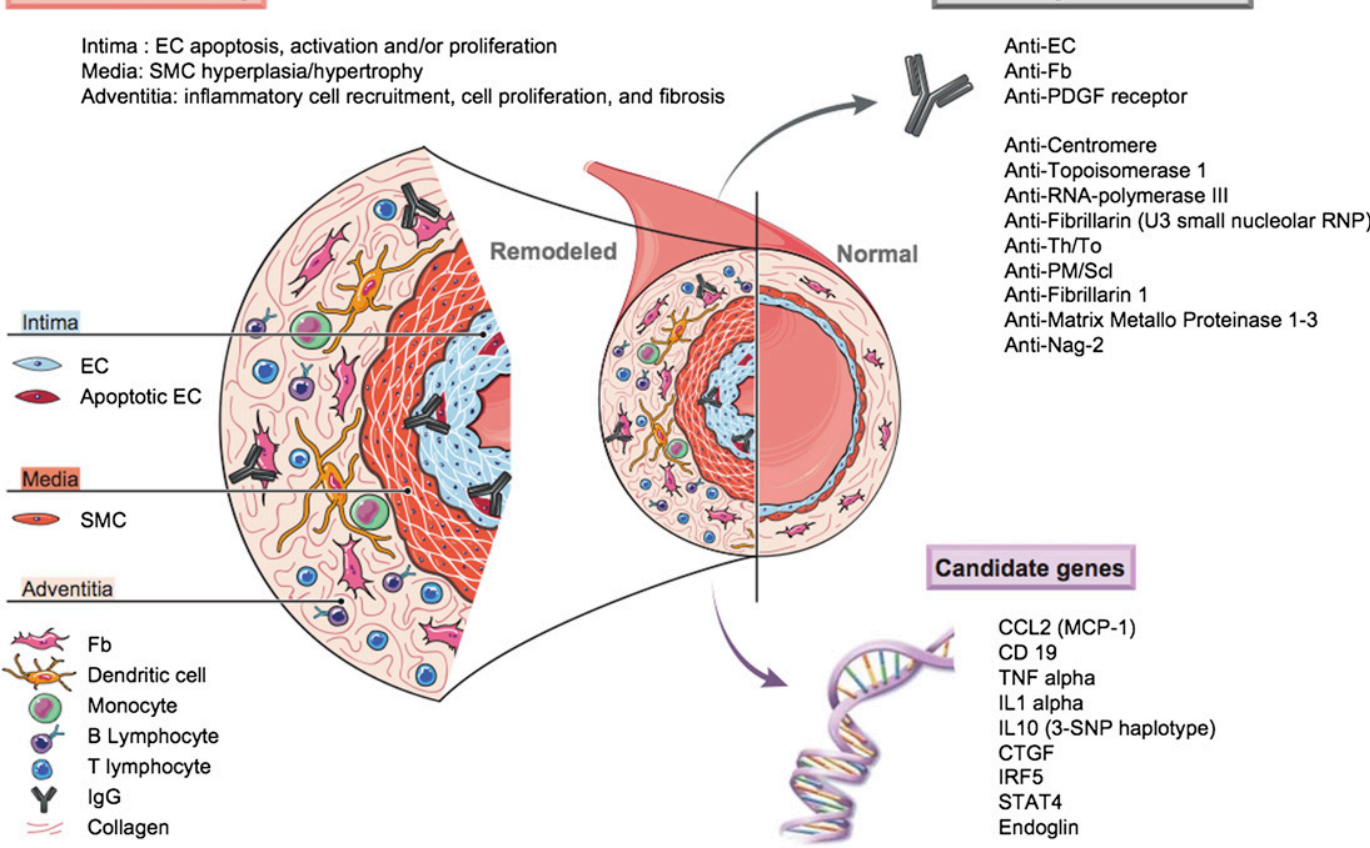

Figure 2. Pulmonary vascular remodeling in systemic sclerosis-related pulmonary arterial hypertension (SSc$\mathrm{PAH})$. This schematic features inflammatory mediators, cells, and mechanisms involved in the pulmonary vascular remodeling of SSc-PAH. Vascular changes affect all three layers (i.e., intima, media, adventitia) of the pulmonary vessel, and involve endothelial cell (EC) apoptosis, EC activation with increased expression of cell adhesion molecules, and inflammatory cell recruitment leading to vessel obliteration. A number of circulating autoantibodies including classic autoantibodies, such as anticentromere, anti-topoisomerase 1, anti-RNA-polymerase III, anti-fibrillarin (U3 small nucleolar ribonucleoprotein [RNP]), anti-Th/To, and antipolymyositis/scleroderma (PM/

$\mathrm{Scl}$ ), and more recently anti-fibrillarin 1, anti-matrix metalloproteinases (MMP) 1-3, anti-novel antigen (nag)-2 (nonsteroidal antiinflammatory drug-activated gene), and evidence that anti-fibroblast (Fb) antibodies, anti-EC antibodies (AECA), and anti-platelet-derived growth factor (PDGF) receptor antibodies might exert a pathogenic role. An increasing number of candidate genes have been reported to be associated with SSc in different cohorts, including, among others, a variant in the promoter of chemokine (C-C motif) ligand 2 (monocytes chemotactic protein-1) (CCL2 [MCP-1]), two variants in cluster of differentiation 19 (CD19), a promoter and coding polymorphism in tumor necrosis factor (TNF)- $\alpha$, a variant in the promoter of IL-1 $\alpha$ gene, a three-single-nucleotide polymorphism (SNP) haplotype in IL-10, a polymorphism in the connective tissue growth factor (CTGF) promoter region, the interferon regulatory factor 5 (IRF5) rs2004640 GT substitution, and the signal transducer and activator of transcription 4 (STAT4) rs7574865 single nucleotide polymorphism. Specific mechanisms are further detailed in the text. SMC $=$ smooth muscle cell.

bodies can activate fibroblasts and induce collagen synthesis, contributing potentially directly to the remodeling process. They induce a proadhesive and proinflammatory response in normal fibroblasts, and have distinct reactivity profiles in IPAH and SSc-PAH, as assessed by immunoblotting (37). Several fibroblast antigens recognized by serum IgG from patients with IPAH and SSc-PAH have so far been identified, including proteins involved in regulation of cytoskeletal function, cell contraction, cell and oxidative stress, cell energy metabolism, and other key cellular pathways (37).

\section{Candidate Genes}

Although case studies to date suffer from limited statistical power, an increasing number of candidate genes have been reported to be associated with SSc in different populations, including, among others, a variant in the promoter of chemokine (C-C motif) ligand 2 (monocytes chemotactic protein-1) (38), two variants in cluster of differentiation 19 (39), a promoter and coding polymorphism in tumor necrosis factor- $\alpha$ (40), a variant in the promoter of IL- $1 \alpha$ gene (41), a three single nucleotide polymorphism haplotype in IL-10 (42), a polymorphism in the connective tissue growth factor promoter region (43), the interferon regulatory factor 5 rs2004640 GT substitution (44), and the signal transducer and activator of transcription 4 rs7574865 single nucleotide polymorphism (45). Thus, there are compelling data supporting a genetic basis for SSc. Despite these recent advances in genetics, little is known about genetic involvement in SSc-PAH (46). Mutations in the gene coding for bone morphogenetic protein receptor 2 (a member of the transforming growth factor- $\beta$ receptor family) have not been detected in two small cohorts of SSc-PAH (46,
47). Recently, an association between an endoglin gene polymorphism and SSc-PAH was reported. Wipff and colleagues demonstrated a significant lower frequency of the six-base insertion in intron 7 (6bINS) of endoglin in patients with SSc$\mathrm{PAH}$ as compared with control subjects or patients with SSc but no PAH (48). Endoglin, a homodimeric membrane glycoprotein primarily present on human vascular endothelium, is part of the transforming growth factor- $\beta$ receptor complex. Although endoglin mutations are known causes of hereditary hemorrhagic telangiectasia and have been rarely identified in patients with PAH (49), the functional significance of endoglin polymorphism in patients with SSc remains to be determined.

\section{THE IMPACT OF COMORBIDITIES}

\section{Age}

PAH is a late manifestation of SSc (50), and patients with SScPAH are typically older compared with patients with IPAH at disease onset $(4,6,10,21,51)$. However, the specific role of age at time of diagnosis on overall survival remains uncertain in SSc$\mathrm{PAH}$. Indeed, studies indicate that late disease onset decreases survival in patients with SSc without $\mathrm{PAH}$ (52). A recent multivariate analysis showed that age was not an independent predictor of death, suggesting that age might impact survival only through associated comorbidities (4), which is consistent with a recent analysis reported by Hachulla and colleagues (50).

\section{Myocardial Involvement}

Involvement of the heart in SSc (53) has long been recognized. Primary myocardial manifestations likely result from underlying vascular lesions and fibrosis that impair microcirculation and 
myocardial function, respectively. Early and widespread subclinical cardiac dysfunction, believed to occur in many patients with SSc and a harbinger of poor prognosis, is associated with $70 \%$ mortality at 5 years. Steen and colleagues (54) demonstrated that thallium perfusion defect scores were the single most powerful predictors of mortality. Myocardial involvement can also be detected by echocardiography and MRI, and may be present clinically in up to 15 to $35 \%$ of patients with SSc (53).

In comparison with other forms of PAH, patients with SScPAH are more prone to left heart abnormalities. Although still debated, patients with SSc-PAH may be more likely to have coronary artery disease than patients with IPAH. Myocardial fibrosis in SSc-PAH may lead to cardiac dysfunction and conduction abnormalities (55). Thus, the ability of the right ventricle $(\mathrm{RV})$ to adapt to the pressure overload may be reduced by myocardial inflammation and scarring as supported by evidence on endomyocardial biopsy from patients with SSc, a finding not reported in IPAH (55). Left heart abnormalities, such as left ventricular hypertrophy and left atrial dilatation, are common in SSc-PAH (56). Similarly, heart failure with preserved ejection fraction is more prevalent in SSc-PAH than in IPAH (4). The presence of pericardial effusion in patients with SSc-PAH is believed to be due to increased right atrial pressure (57) but may also be a manifestation of serositis and systemic inflammatory disease (58). Compared with IPAH, pericardial effusion is almost three times more common in patients with SSc-PAH and appears to be a strong predictor of mortality (4).

\section{Musculoskeletal Involvement}

Musculoskeletal involvement is frequent in patients with SSc and is a major cause of disability, but is unlikely to significantly affect overall prognosis, which largely depends on the degree of visceral involvement (59). Joint involvement is present in 12 to $66 \%$ of patients at the time of diagnosis and from 24 to $97 \%$ of patients at some time during the disease course (59). However, the prevalence and distribution of joint involvement have not been accurately defined. Muscle involvement occurs in 16 to $81 \%$ of cases (60), is more prevalent in diffuse SSc (60), and correlates strongly with myocardial disease in SSc (59). In an analysis of more than 300 patients with SSc, diffuse SSc, the presence of pulmonary fibrosis, and male sex were risk factors for development of myopathy (61). Although the role of musculoskeletal involvement in overall prognosis is unclear, it does impact function, such as the 6-minute walk distance (6MWD) as recently suggested (62), raising very strong doubts about the validity and reliability of this functional end point in $\mathrm{SSc}-\mathrm{PAH}$

\section{Pulmonary Fibrosis}

Patients with limited SSc disease will typically develop isolated PAH 10 to 15 years after the onset of their disease (63). In contrast, patients with diffuse SSc are at greater risk for interstitial lung disease (ILD), usually within the first 5 years after diagnosis when the most rapid rate of decline in FVC is observed (17), but may develop pulmonary hypertension ( $\mathrm{PH})$ at any stage in the course of their disease. Although $\mathrm{PH}$ is generally modest (mean pulmonary arterial pressure [PAP] 25-35 $\mathrm{mm} \mathrm{Hg}$ ) in patients with ILD, PAP elevations can be more substantial (mean PAP $35-50 \mathrm{~mm} \mathrm{Hg}$ ) in some patients, particularly those with only moderate pulmonary function impairment. In this case, $\mathrm{PH}$ is considered out of proportion to the degree of lung impairment (64). However, although patients with SSc with ILD alone have a median survival of 5 to 8 years, development of PH (PH-ILD) will shorten survival significantly, as suggested by Trad and colleagues (65) and more recently by Mathai and colleagues (66). In multivariate analysis, PH-ILD was associated with a fivefold increased risk of death compared with SSc-PAH (66). Similarly, in a recent large study by Condliffe and colleagues, the 3 -year survival was significantly worse $(28 \%)$ in the group of patients with ILD compared with patients with isolated SSc-PAH (47\%) (20).

\section{Pulmonary Venoocclusive Disease}

Pulmonary venoocclusive disease (PVOD) is characterized by intimal proliferation and fibrosis of the intrapulmonary veins and venules, occasionally extending to the arteriolar bed (26). Although definite diagnosis of PVOD requires histologic analysis of a lung sample (67), surgical lung biopsy is risky in this patient population, emphasizing the importance of developing less-invasive tools to obtain the diagnosis (67). PVOD is an underrecognized pulmonary vascular disease in patients presenting with SSc-PAH (67). However, awareness is important considering the very poor response to available therapy and the risk of pulmonary edema with the use of vasodilators in this condition (67). Compared with PAH, PVOD is characterized by a higher male/female ratio, higher prevalence of tobacco exposure, lower arterial oxygen tension at rest, lower diffusing capacity of the lung for carbon monoxide, and lower oxygen saturation nadir during the 6-minute walk test. In addition, high-resolution computed tomography of the chest can be suggestive of PVOD in the presence of centrilobular groundglass opacities, septal lines, and lymph node enlargement (67). Two recent histological studies suggested that SSc-PAH may be characterized by a more frequent involvement of pulmonary veins than previously recognized, perhaps explaining in part why these patients are less responsive to specific PAH treatment as compared with patients with IPAH $(26,68)$. Lung transplantation remains the only suitable alternative for most patients with PVOD.

\section{LACK OF RELIABILITY OF CURRENT EVALUATION TOOLS}

\section{The 6-Minute Walk Test}

Description of baseline characteristics for patients with SScPAH is limited $(4,6,10,21)$; they tend to have seemingly less severe alterations in hemodynamics compared with patients with IPAH $(4,10,21)$ despite similar 6MWD values between the two groups $(4,10)$. Therefore, these findings question the ability of the 6MWD as well as traditional baseline hemodynamics (obtained by RHC) to accurately assess the severity of SSc-PAH. Because of its simplicity, reproducibility, and validity in reflecting severity in patients with IPAH, the 6MWD has been widely accepted and is recommended in the baseline assessment of patients with $\mathrm{PAH}$ for prognostication and monitoring response to therapy. However, this test has never been independently validated in SSc-PAH (69). A recent metaanalysis of 10 randomized clinical trials involving treatment with the endothelin receptor antagonists bosentan and sitaxsentan and the phosphodiesterase inhibitor sildenafil in a total of 613 patients with PAH, of whom 117 with SSc-PAH received active treatment and 36 with $\mathrm{SSc}-\mathrm{PAH}$ received placebo, demonstrated a significant improvement in IPAH but nonsignificant improvement in 6MWD in patients with SScPAH (70). Whether these results reflect limited efficacy (e.g., stabilization) or lack of responsiveness to these therapies in the patients with SSc is unclear. Furthermore, because the 6-minute walk test includes the ability to assess a global and integrated response of systems required for daily functioning, many of the confounders and comorbidities discussed above, such as pain and musculoskeletal dysfunction, will reduce the reliability and 
validity of this test in SSc, as recently shown in patients with SSc-PAH (62).

\section{Right Heart Catheterization}

Cardiopulmonary hemodynamic abnormalities are required for the diagnosis of PAH and offer the best established indicators of the severity of the illness. Right atrial pressure, decreased cardiac index, and increased mean PAP are predictors of death or need for lung transplantation in IPAH (71). More recent studies demonstrated that baseline resting hemodynamic measurements offer valuable information in terms of severity and prognosis. However, although these data have generally been validated in IPAH, they remain of unclear usefulness in SScPAH. Indeed, recent studies have highlighted the lack of correlation between baseline hemodynamic data and clinical evolution in patients with SSc-PAH. In a retrospective analysis comparing baseline hemodynamic data in patients with IPAH and SSc-PAH, patients with SSc-PAH had significantly lower mean PAP and pulmonary vascular resistance by RHC and equally depressed cardiac index compared with patients with IPAH; however, follow-up indicated they were four times more likely to die compared with patients with IPAH despite comparable therapy (4). These seemingly paradoxical findings suggest that the RV may have a reduced ability to adapt to increased pulmonary vascular resistance in SSc-PAH, perhaps related in part to myocardial inflammation and scarring as supported by endomyocardial biopsy samples from patients with SSc (55). Taken together, these results suggest that, in the setting of SSc, the ability of RHC to evaluate the severity of PAH may be limited.

\section{CURRENT MEDICAL THERAPIES FOR SSC-PAH}

The effect, or lack thereof, of current medical therapy for SScPAH has been covered elsewhere (72). However, a few points are worth mentioning.

Calcium channel blockers are usually not indicated for patients with SSc-PAH, although most patients often receive these drugs at low dosage, typically for Raynaud syndrome (72).

Continuous intravenous epoprostenol, which improves exercise capacity and hemodynamics compared with conventional therapy in SSc-PAH even if no demonstrable effect on survival has ever been shown (73), remains a valuable therapeutic option for patients with SSc-PAH with New York Heart Association class IV and in functional class III patients who fail to improve on first-line therapy.

Regarding endothelin receptor antagonists, a recent analysis of patients with connective tissue disease-associated $\mathrm{PAH}$ included in randomized clinical trials of bosentan demonstrated a trend toward improvement in 6MWD (however, far from the effects observed in patients with IPAH) and improved survival compared with historical cohorts (74). Aside from potentially improving pulmonary hypertension, endothelin receptor antagonists cause significant reduction in the occurrence of new digital ulcerations without, however, healing preexisting ulcers (75).

Randomized clinical trials with phosphodiesterase inhibitors, such as sildenafil and tadalafil, have included patients with PAH related to connective tissue diseases (e.g., SSc-PAH). In a post hoc subgroup analysis of 84 patients with $\mathrm{PAH}$ related to connective tissue disease, there is modest effect of sildenafil on exercise capacity, hemodynamic measures, and functional class after 12 weeks of treatment (76). The specific effects of tadalafil on SSc-PAH are unknown, as subgroup analysis has not been reported to date (77).

It is now common practice in various pulmonary hypertension centers to add drugs when patients fail to improve on monotherapy. A small, nonrandomized study examined the effect of adding sildenafil for patients with IPAH or SSc-PAH after they failed initial monotherapy with bosentan (78). Although the combination improved 6MWD and functional class in patients with IPAH, the outcome in patients with SScPAH was less favorable. However, clinical deterioration may have been slowed in these patients.

Patients with SSc have long been considered suboptimal candidates for lung or heart-lung transplantation. Presumed heightened risk in the postoperative period, arising from SSc-related gastroesophageal reflux, renal impairment, or skin fibrosis, likely contributes to this perception. However, the results of two recent studies $(79,80)$ suggest that lung transplantation, in carefully selected patients, may represent a viable therapeutic option in patients with end-stage lung dysfunction resulting from SSc. Transplant experts now suggest that candidates for transplantation should be evaluated on an individual basis.

\section{FUTURE DIRECTIONS FOR MEDICAL THERAPIES}

The recognition of aberrant proliferation of endothelial and smooth muscle cells in PAH has prompted the study of antineoplastic drugs initially in experimental models, and now in clinical trials. Two strategies are currently under investigation in randomized controlled trials: disruption of the PDGF pathway and the vascular endothelial growth factor pathway. STI-571/imatinib, which was originally developed to inhibit the Bcr-Abl kinase in the treatment of chronic myelogenous leukemia, is also a PDGF and c-kit tyrosine inhibitor that is currently under investigation for the treatment of PAH. A few case reports $(81,82)$ have suggested its usefulness, including one in a patient with SScPAH and in a patient with PVOD (83). It is also noteworthy that imatinib is currently being studied for the treatment of SScrelated ILD and skin disease with the notion that dysregulated proliferation and increased growth factors are prevalent in SSc and may be involved in the pathogenesis of SSc.

In summary, the paucity of information on current medical therapy in SSc-PAH, and the poor outcomes noted by several investigators, suggests an urgent need for new pathways to target and randomized clinical trials specifically tailored to this clinical entity. Because of the higher likelihood of medical treatment failures in SSc-PAH, it should also be emphasized that eligible patients should be considered for lung transplantation when they meet the criteria for listing (80).

\section{FUTURE PERSPECTIVES}

\section{Early Diagnosis}

Because the prevalence of PAH in SSc is high, this population may be considered at risk and therefore worthy of a specific diagnostic approach to detect the presence of disease at an earlier stage, when therapeutic intervention may potentially improve outcome. An algorithm for detection of $\mathrm{PAH}$ in patients with SSc may be helpful if based on a combination of symptoms and screening echocardiography. In a large French study encompassing 21 referral centers, patients with SSc with tricuspid regurgitation velocity jet by transthoracic echocardiography greater than $3 \mathrm{~m} / \mathrm{sec}$, or between 2.5 and $3 \mathrm{~m} / \mathrm{sec}$ if accompanied by unexplained dyspnea, were systematically referred for RHC. This approach allowed detection of incident cases of SSc-PAH with less severe disease (as judged on hemodynamic data) compared with patients with known disease. Therefore, unexplained dyspnea should prompt a search for $\mathrm{PAH}$ in these patients, in particular in the setting of a low single-breath $\mathrm{DL}_{\mathrm{CO}}$ or declining $\mathrm{DL}_{\mathrm{CO}}$ over time, echocardiographic findings suggestive of the disease (elevated tricuspid 
regurgitation velocity jet or dilated $\mathrm{RV}$ or atrium), or elevated levels of $\mathrm{N}$-terminal pro-brain natriuretic peptide (N-TproBNP) (see below) (7) (Figure 3). However, whether early diagnosis and treatment of patients with SSc-PAH improves outcomes is still uncertain (84); this issue should be addressed in properly designed studies to control for confounders such as lead time bias.

\section{Assessing Markers of Severity}

The development of treatments for PAH has brought to the forefront the question of how to best assess and monitor the efficacy of long-term therapy. For the reasons mentioned above, alternative strategies are required to measure and compare the relative effects of available treatments in SSc-PAH. A call for noninvasive and clinically relevant markers of disease severity has been made and some are already currently tested (85).

Over the past few years, NT-proBNP has been studied in various forms of $\mathrm{PAH}$ populations and found to be useful in predicting development of $\mathrm{PAH}$ in patients with $\mathrm{SSc}$ and survival (86). NT-proBNP serum levels are significantly higher in SSc-PAH (compared with patients with IPAH) despite less severe hemodynamic perturbations (87) for reasons that remain unclear but would suggest more profound cardiac dysfunction.

A strong correlation between hyponatremia, as a marker of neurohormonal activation, and RV dysfunction and survival was demonstrated in a cohort of patients with PAH (23), where patients with SSc-PAH were more likely to be hyponatremic than patients with IPAH despite similar hemodynamics, suggesting possible differences in neurohormonal activation between the two groups. These as well as other specific markers of disease and disease severity should be identified.

\section{Evaluation of the RV}

Whether in IPAH or SSc-PAH, cardiac (particularly RV) function is the single most important determinant of survival and should be the focus of more investigation. Overbeek and colleagues compared the relationship between mean RV pres- sure and stroke volume in a limited number of patients with SSc-PAH and IPAH. Although both groups had similar right atrial pressure and cardiac index, patients with SSc-PAH demonstrated lower stroke volumes for any given mean RV pressure, suggesting significantly impaired RV contractility (51). Whether these findings explain the early occurrence of RV failure and death in this patient population needs to be determined; however, these results highlight the need for a more accurate evaluation of the RV pump, particularly in the setting of SSc-PAH.

Cardiac MRI has become the gold standard for quantitative evaluation of RV structural changes; it allows accurate and reproducible measurements of ventricular dimensions, wall thickness, and myocardial mass without relying on geometric assumptions. It enables precise analysis of the different patterns of heart involvement in SSc by differentiating morphological, functional, perfusion, and delayed contrast enhancement abnormalities. Compared with other imaging modalities, cardiac MRI detects significantly compromised RV function in a higher number of patients with asymptomatic SSc and thus may become an invaluable tool in detecting subclinical involvement in these patients $(88)$

\section{CONCLUSION}

Despite major advances in the understanding and management of PAH, SSc-PAH remains a dreadful disease with poor response to modern therapy. Currently available markers of disease severity and clinical tools to assess therapeutic response are either limited or lacking in this disease. We believe there is an urgent need to identify specific pathogenic mechanisms and design novel physiologic, molecular, and imaging biomarkers that will allow a better understanding of the underlying pathogenesis and serve as reliable tools to design targeted therapy and adequately monitor response in this devastating syndrome. We recommend a multidisciplinary approach that
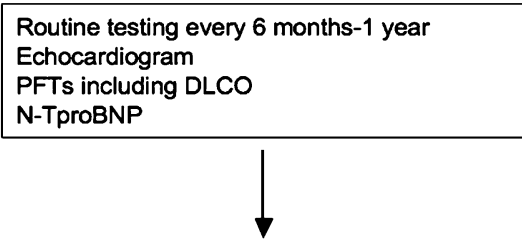

Clinical suspicion based on any of the following:

Unexplained dyspnea

Physical findings

Low DLCO

$\uparrow$ FVC\%/DLCO\%

High N-TproBNP

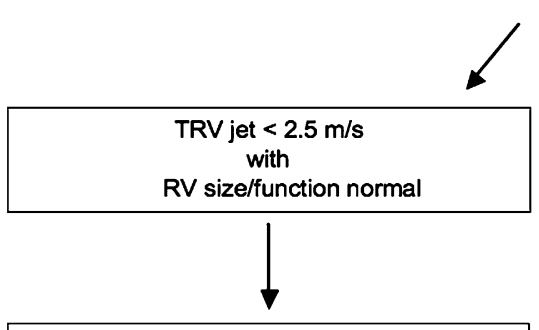

No PAH suspicion: continue observation

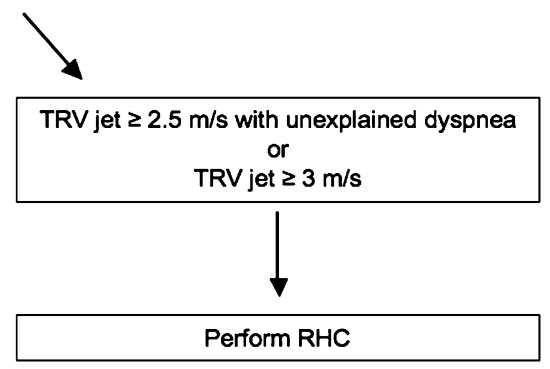

Figure 3. Algorithm for detection of pulmonary arterial hypertension (PAH) in patients with systemic sclerosis (SSC). Proposed algorithm for performance of routine clinical tests in patients with SSC that may allow early detection of PAH or other causes of dyspnea (e.g., cardiac dysfunction). $\mathrm{DL}_{\mathrm{CO}}=$ single breath diffusing capacity of carbon monoxide; PFTs = pulmonary function tests; $\mathrm{RHC}=$ right heart catheterization; $\mathrm{RV}=$ right ventricle; TRV $=$ tricuspid regurgitation jet. 
will ensure comprehensive therapy and monitoring. Whether early diagnosis and treatment of patients with SSc-PAH improves outcomes is still uncertain and needs to be confirmed in properly designed studies.

Conflict of Interest Statement: J.L.P. does not have a financial relationship with a commercial entity that has an interest in the subject of this manuscript. M.H. received $\$ 5,001-\$ 10,000$ from Actelion, $\$ 1,001-\$ 5,000$ from Novartis, $\$ 1,001$ $\$ 5,000$ from GlaxoSmithKline, and $\$ 1,001-\$ 5,000$ from MSD in advisory board fees; and $\$ 5,001-\$ 10,000$ from Actelion, $\$ 1,001-\$ 5,000$ from BayerSchering, $\$ 1,001-\$ 5,000$ from GlaxoSmithKine, $\$ 1,001-\$ 5,000$ from Novartis, and up to $\$ 1,000$ from United Therapeutics in lecture fees. L.M. received $\$ 1,001$ $\$ 5,000$ from Actelion, $\$ 1,001-\$ 5,000$ from Pfizer, and up to $\$ 1,000$ from GlaxoSmithKline in consultancy fees; $\$ 1,001-\$ 5,000$ from Pfizer and $\$ 1,001$ $\$ 5,000$ from Actelion in advisory board fees; and up to $\$ 1,000$ from Pfizer, $\$ 1,001-\$ 5,000$ from Actelion, and up to $\$ 1,000$ from Glaxo\$mithKline in lecture fees. L.M.'s dependent received $\$ 50,001-\$ 100,000$ from Actelion in industrysponsored grants for study on beliefs and fears in systemic sclerosis and more than $\$ 100,001$ from Pfizer in industry-sponsored grants for autoimmunity in PAH. P.M.H. received $\$ 1,001-\$ 5,000$ from Novartis in advisory board fees and $\$ 50,001-\$ 100,000$ from Cotherix in industry-sponsored grants for the creation of PAH Registry.

\section{References}

1. Jimenez SA, Derk CT. Following the molecular pathways toward an understanding of the pathogenesis of systemic sclerosis. Ann Intern Med 2004;140:37-50.

2. Tan FK. Systemic sclerosis: the susceptible host (genetics and environment). Rheum Dis Clin North Am 2003;29:211-237.

3. Steen VD, Medsger TA. Changes in causes of death in systemic sclerosis, 1972-2002. Ann Rheum Dis 2007;66:940-944.

4. Fisher MR, Mathai SC, Champion HC, Girgis RE, Housten-Harris T, Hummers L, Krishnan JA, Wigley F, Hassoun PM. Clinical differences between idiopathic and scleroderma-related pulmonary hypertension. Arthritis Rheum 2006;54:3043-3050.

5. Hachulla E, Carpentier P, Gressin V, Diot E, Allanore Y, Sibilia J, Launay D, Mouthon L, Jego P, Cabane J, et al. Risk factors for death and the 3-year survival of patients with systemic sclerosis: the French ItinérAIR-Sclerodérmie study. Rheumatology (Oxford) 2009;48:304 308.

6. Kawut SM, Taichman DB, Archer-Chicko CL, Palevsky HI, Kimmel SE. Hemodynamics and survival in patients with pulmonary arterial hypertension related to systemic sclerosis. Chest 2003;123:344-350.

7. Hachulla E, Gressin V, Guillevin L, Carpentier P, Diot E, Sibilia J, Kahan A, Cabane J, Frances C, Launay D, et al. Early detection of pulmonary arterial hypertension in systemic sclerosis: a French nationwide prospective multicenter study. Arthritis Rheum 2005;52: 3792-3800.

8. Mukerjee D, St George D, Coleiro B, Knight C, Denton CP, Davar J, Black CM, Coghlan JG. Prevalence and outcome in systemic sclerosis associated pulmonary arterial hypertension: application of a registry approach. Ann Rheum Dis 2003;62:1088-1093.

9. Gaine SP, Rubin LJ. Primary pulmonary hypertension. Lancet 1998;352: $719-725$.

10. Humbert M, Sitbon O, Chaouat A, Bertocchi M, Habib G, Gressin V Yaici A, Weitzenblum E, Cordier JF, Chabot F, et al. Pulmonary arterial hypertension in France: results from a national registry. Am J Respir Crit Care Med 2006;173:1023-1030.

11. Mayes MD. Scleroderma epidemiology. Rheum Dis Clin North Am 2003;29:239-254.

12. Thenappan T, Shah SJ, Rich S, Gomberg-Maitland M. A USA-based registry for pulmonary arterial hypertension: 1982-2006. Eur Respir J 2007;30:1103-1110.

13. Hachulla E, de Groote P, Gressin V, Sibilia J, Diot E, Carpentier P, Mouthon L, Hatron PY, Jego P, Allanore Y, et al. The 3-year incidence of pulmonary arterial hypertension associated with systemic sclerosis in a multicenter nationwide longitudinal study (ItinérAIRSclérodermie study). Arthritis Rheum 2009;60:1831-1839.

14. Chang B, Schachna L, White B, Wigley FM, Wise RA. Natural history of mild-moderate pulmonary hypertension and the risk factors for severe pulmonary hypertension in scleroderma. J Rheumatol 2006; 33:269-274.

15. Cox SR, Walker JG, Coleman M, Rischmueller M, Proudman S, Smith MD, Ahern MJ, Roberts-Thomson PJ. Isolated pulmonary hypertension in scleroderma. Intern Med J 2005;35:28-33.
16. Hachulla E, Coghlan JG. A new era in the management of pulmonary arterial hypertension related to scleroderma: endothelin receptor antagonism. Ann Rheum Dis 2004;63:1009-1014.

17. Steen V. Predictors of end stage lung disease in systemic sclerosis. Ann Rheum Dis 2003;62:97-99.

18. Plastiras SC, Karadimitrakis SP, Kampolis C, Moutsopoulos HM, Tzelepis GE. Determinants of pulmonary arterial hypertension in scleroderma. Semin Arthritis Rheum 2007;36:392-396.

19. Ong YY, Nikoloutsopoulos T, Bond CP, Smith MD, Ahern MJ, Roberts-Thomson PJ. Decreased nailfold capillary density in limited scleroderma with pulmonary hypertension. Asian Pac $J$ Allergy Immunol 1998;16:81-86.

20. Condliffe R, Kiely DG, Peacock AJ, Corris PA, Gibbs JS, Vrapi F, Das C, Elliot CA, Johnson M, DeSoyza J, et al. Connective tissue diseaseassociated pulmonary arterial hypertension in the modern treatment era. Am J Respir Crit Care Med 2009;179:151-157.

21. Girgis RE, Mathai SC, Krishnan JA, Wigley FM, Hassoun PM. Longterm outcome of bosentan treatment in idiopathic pulmonary arterial hypertension and pulmonary arterial hypertension associated with the scleroderma spectrum of diseases. J Heart Lung Transplant 2005;24: 1626-1631.

22. Forfia PR, Fisher MR, Mathai SC, Housten-Harris T, Hemnes AR, Borlaug BA, Chamera E, Corretti MC, Champion HC, Abraham TP, et al. Tricuspid annular displacement predicts survival in pulmonary hypertension. Am J Respir Crit Care Med 2006;174:1034-1041.

23. Forfia PR, Mathai SC, Fisher MR, Housten-Harris T, Hemnes AR, Champion HC, Girgis RE, Hassoun PM. Hyponatremia predicts right heart failure and poor survival in pulmonary arterial hypertension. Am J Respir Crit Care Med 2008;177:1364-1369.

24. Hassoun PM, Mouthon L, Barbera JA, Eddahibi S, Flores SC, Grimminger F, Jones PL, Maitland ML, Michelakis ED, Morell $\mathrm{NW}$, et al. Inflammation, growth factors and pulmonary vascular remodeling. J Am Coll Cardiol 2009;54:S10-S19.

25. Tuder RM, Groves B, Badesch DB, Voelkel NF. Exuberant endothelial cell growth and elements of inflammation are present in plexiform lesions of pulmonary hypertension. Am J Pathol 1994;144:275-285.

26. Dorfmuller P, Humbert M, Perros F, Sanchez O, Simonneau G, Muller KM, Capron F. Fibrous remodeling of the pulmonary venous system in pulmonary arterial hypertension associated with connective tissue diseases. Hum Pathol 2007;38:893-902.

27. Sgonc R, Gruschwitz MS, Boeck G, Sepp N, Gruber J, Wick G. Endothelial cell apoptosis in systemic sclerosis is induced by antibody-dependent cell-mediated cytotoxicity via CD95. Arthritis Rheum 2000;43:2550-2562.

28. Cerinic MM, Valentini G, Sorano GG, D'Angelo S, Cuomo G, Fenu L, Generini S, Cinotti S, Morfini M, Pignone A, et al. Blood coagulation, fibrinolysis, and markers of endothelial dysfunction in systemic sclerosis. Semin Arthritis Rheum 2003;32:285-295.

29. Choi JJ, Min DJ, Cho ML, Min SY, Kim SJ, Lee SS, Park KS, Seo YI, Kim WU, Park SH, et al. Elevated vascular endothelial growth factor in systemic sclerosis. J Rheumatol 2003;30:1529-1533.

30. Distler O, Del Rosso A, Giacomelli R, Cipriani P, Conforti ML, Guiducci S, Gay RE, Michel BA, Bruhlmann P, Muller-Ladner U, et al. Angiogenic and angiostatic factors in systemic sclerosis: increased levels of vascular endothelial growth factor are a feature of the earliest disease stages and are associated with the absence of fingertip ulcers. Arthritis Res 2002;4:R11.

31. Gabrielli A, Avvedimento EV, Krieg T. Scleroderma. N Engl J Med 2009;360:1989-2003.

32. Morse JH, Barst RJ, Fotino M, Zhang Y, Flaster E, Gharavi AE, Fritzler MJ, Dominguez M, Angles-Cano E. Primary pulmonary hypertension, tissue plasminogen activator antibodies, and HLA-DQ7. Am J Respir Crit Care Med 1997;155:274-278

33. Grigolo B, Mazzetti I, Meliconi R, Bazzi S, Scorza R, Candela M, Gabrielli A, Facchini A. Anti-topoisomerase II alpha autoantibodies in systemic sclerosis-association with pulmonary hypertension and HLA-B35. Clin Exp Immunol 2000;121:539-543.

34. Nicolls MR, Taraseviciene-Stewart L, Rai PR, Badesch DB, Voelkel NF. Autoimmunity and pulmonary hypertension: a perspective. Eur Respir J 2005;26:1110-1118.

35. Okawa-Takatsuji M, Aotsuka S, Fujinami M, Uwatoko S, Kinoshita M, Sumiya M. Up-regulation of intercellular adhesion molecule-1 (ICAM-1), endothelial leucocyte adhesion molecule-1 (ELAM-1) and class II MHC molecules on pulmonary artery endothelial cells by antibodies against U1-ribonucleoprotein. Clin Exp Immunol 1999; 116:174-180. 
36. Tamby MC, Humbert M, Guilpain P, Servettaz A, Dupin N, Christner JJ, Simonneau G, Fermanian J, Weill B, Guillevin L, et al. Antibodies to fibroblasts in idiopathic and scleroderma-associated pulmonary hypertension. Eur Respir J 2006;28:799-807.

37. Terrier B, Tamby MC, Camoin L, Guilpain P, Broussard C, Bussone G, Yaici A, Hotellier F, Simonneau G, Guillevin L, et al. Identification of target antigens of antifibroblast antibodies in pulmonary arterial hypertension. Am J Respir Crit Care Med 2008;177:1128-1134.

38. Karrer S, Bosserhoff AK, Weiderer P, Distler O, Landthaler M, Szeimies RM, Muller-Ladner U, Scholmerich J, Hellerbrand C. The -2518 promotor polymorphism in the MCP-1 gene is associated with systemic sclerosis. J Invest Dermatol 2005;124:92-98.

39. Tsuchiya N, Kuroki K, Fujimoto M, Murakami Y, Tedder TF, Tokunaga K, Takehara K, Sato S. Association of a functional CD19 polymorphism with susceptibility to systemic sclerosis. Arthritis Rheum 2004;50:4002-4007.

40. Tolusso B, Fabris M, Caporali R, Cuomo G, Isola M, Soldano F, Montecucco C, Valentini G, Ferraccioli G. -238 and + 489 TNF-alpha along with TNF-RII gene polymorphisms associate with the diffuse phenotype in patients with systemic sclerosis. Immunol Lett 2005;96: $103-108$.

41. Hutyrova B, Lukac J, Bosak V, Buc M, du Bois R, Petrek M. Interleukin 1alpha single-nucleotide polymorphism associated with systemic sclerosis. J Rheumatol 2004;31:81-84.

42. Crilly A, Hamilton J, Clark CJ, Jardine A, Madhok R. Analysis of the 5 flanking region of the interleukin 10 gene in patients with systemic sclerosis. Rheumatology (Oxford) 2003;42:1295-1298.

43. Fonseca C, Lindahl GE, Ponticos M, Sestini P, Renzoni EA, Holmes AM, Spagnolo $\mathrm{P}$, Pantelidis $\mathrm{P}$, Leoni $\mathrm{P}$, McHugh $\mathrm{N}$, et al. A polymorphism in the CTGF promoter region associated with systemic sclerosis. N Engl J Med 2007;357:1210-1220.

44. Dieude P, Guedj M, Wipff J, Avouac J, Fajardy I, Diot E, Granel B, Sibilia J, Cabane J, Mouthon L, et al. Association between the IRF5 rs2004640 functional polymorphism and systemic sclerosis: a new perspective for pulmonary fibrosis. Arthritis Rheum 2009;60:225-233.

45. Dieude P, Guedj M, Wipff J, Ruiz B, Hachulla E, Diot E, Granel B, Sibilia J, Tiev K, Mouthon L, et al. STAT4 is a genetic risk factor for systemic sclerosis having additive effects with IRF5 on disease susceptibility and related pulmonary fibrosis. Arthritis Rheum 2009; 60:2472-2479.

46. Morse J, Barst R, Horn E, Cuervo N, Deng Z, Knowles J. Pulmonary hypertension in scleroderma spectrum of disease: lack of bone morphogenetic protein receptor 2 mutations. J Rheumatol 2002;29: 2379-2381.

47. Tew MB, Arnett FC, Reveille JD, Tan FK. Mutations of bone morphogenetic protein receptor type ii are not found in patients with pulmonary hypertension and underlying connective tissue diseases. Arthritis Rheum 2002;46:2829-2830.

48. Wipff J, Kahan A, Hachulla E, Sibilia J, Cabane J, Meyer O, Mouthon L, Guillevin L, Junien C, Boileau C, et al. Association between an endoglin gene polymorphism and systemic sclerosis-related pulmonary arterial hypertension. Rheumatology (Oxford) 2007;46:622-625.

49. Machado RD, Eickelberg O, Elliott CG, Geraci MW, Hanaoka M, Loyd JE, Newman JH, Phillips JA III, Soubrier F, Trembath RC, et al. Genetics and genomics of pulmonary arterial hypertension. J Am Coll Cardiol 2009;54:S32-S42.

50. Hachulla E, Launay D, Mouthon L, Sitbon O, Berezne A, Guillevin L, Hatron PY, Simonneau G, Clerson P, Humbert M. Is pulmonary arterial hypertension really a late complication of systemic sclerosis? Chest 2009;136:1211-1219.

51. Overbeek MJ, Lankhaar JW, Westerhof N, Voskuyl AE, BoonstraA, Bronzwaer JG, Marques KM, Smit EF, Dijkmans BA, Vonk-Noordegraaf A. Right ventricular contractility in systemic sclerosis-associated and idiopathic pulmonary arterial hypertension. Eur Respir J 2008;31:1160-1166.

52. Mayes MD, Lacey JV Jr, Beebe-Dimmer J, Gillespie BW, Cooper B, Laing TJ, Schottenfeld D. Prevalence, incidence, survival, and disease characteristics of systemic sclerosis in a large us population. Arthritis Rheum 2003;48:2246-2255.

53. Kahan A, Coghlan G, McLaughlin V. Cardiac complications of systemic sclerosis. Rheumatology (Oxford) 2009;48:iii45-iii48.

54. Steen VD, Follansbee WP, Conte CG, Medsger TA Jr. Thallium perfusion defects predict subsequent cardiac dysfunction in patients with systemic sclerosis. Arthritis Rheum 1996;39:677-681.

55. Fernandes F, Ramires FJ, Arteaga E, Ianni BM, Bonfa ES, Mady C. Cardiac remodeling in patients with systemic sclerosis with no signs or symptoms of heart failure: an endomyocardial biopsy study. $J$ Card Fail 2003;9:311-317.

56. de Groote P, Gressin V, Hachulla E, Carpentier P, Guillevin L, Kahan A, Cabane J, Frances C, Lamblin N, Diot E, et al. Evaluation of cardiac abnormalities by Doppler echocardiography in a large nationwide multicentric cohort of patients with systemic sclerosis. Ann Rheum Dis 2008;67:31-36.

57. Hinderliter AL, Willis PW 4th, Long W, Clarke WR, Ralph D, Caldwell EJ, Williams W, Ettinger NA, Hill NS, Summer WR, et al. Frequency and prognostic significance of pericardial effusion in primary pulmonary hypertension. PPH study group. Primary pulmonary hypertension. Am J Cardiol 1999;84:481-484, A410.

58. Thompson AE, Pope JE. A study of the frequency of pericardial and pleural effusions in scleroderma. Br J Rheumatol 1998;37:1320-1323.

59. Randone SB, Guiducci S, Cerinic MM. Musculoskeletal involvement in systemic sclerosis. Best Pract Res Clin Rheumatol 2008;22:339-350.

60. Ranque B, Authier FJ, Berezne A, Guillevin L, Mouthon L. Systemic sclerosis-associated myopathy. Ann N Y Acad Sci 2007;1108:268-282.

61. Mimura Y, Ihn H, Jinnin M, Asano Y, Yamane K, Tamaki K. Clinical and laboratory features of scleroderma patients developing skeletal myopathy. Clin Rheumatol 2005;24:99-102.

62. Garin MC, Highland KB, Silver RM, Strange C. Limitations to the 6minute walk test in interstitial lung disease and pulmonary hypertension in scleroderma. J Rheumatol 2009;36:330-336.

63. Steen V, Medsger TA Jr. Predictors of isolated pulmonary hypertension in patients with systemic sclerosis and limited cutaneous involvement. Arthritis Rheum 2003;48:516-522.

64. Simonneau G, Robbins IM, Beghetti M, Channick RN, Delcroix M, Denton CP, Elliott CG, Gaine SP, Gladwin MT, Jing ZC, et al. Updated clinical classification of pulmonary hypertension. J Am Coll Cardiol 2009·54:S43-S54.

65. Trad S, Amoura Z, Beigelman C, Haroche J, Costedoat N, Boutin le TH, Cacoub P, Frances C, Wechsler B, Grenier P, et al. Pulmonary arterial hypertension is a major mortality factor in diffuse systemic sclerosis, independent of interstitial lung disease. Arthritis Rheum 2006:54:184-191.

66. Mathai SC, Hummers LK, Champion HC, Wigley FM, Zaiman A, Hassoun PM, Girgis RE. Survival in pulmonary hypertension associated with the scleroderma spectrum of diseases: impact of interstitial lung disease. Arthritis Rheum 2009;60:569-577.

67. Montani D, Price LC, Dorfmuller P, Achouh L, Jais X, Yaici A, Sitbon O, Musset D, Simonneau G, Humbert M. Pulmonary veno-occlusive disease. Eur Respir J 2009;33:189-200.

68. Overbeek MJ, Vonk MC, Boonstra A, Voskuyl AE, Vonk-Noordegraaf A, Smit EF, Dijkmans BA, Postmus PE, Mooi WJ, Heijdra Y, et al. Pulmonary arterial hypertension in limited cutaneous systemic sclerosis: a distinctive vasculopathy. Eur Respir J 2009;34:371-379.

69. Pamidi S, Mehta S. Six-minute walk test in scleroderma-associated pulmonary arterial hypertension: are we counting what counts? J Rheumatol 2009;36:216-218.

70. Avouac J, Wipff J, Kahan A, Allanore Y. Effects of oral treatments on exercise capacity in systemic sclerosis related pulmonary arterial hypertension: a meta-analysis of randomised controlled trials. Ann Rheum Dis 2008;67:808-814.

71. D'Alonzo GE, Barst RJ, Ayres SM, Bergofsky EH, Brundage BH, Detre KM, Fishman AP, Goldring RM, Groves BM, Kernis JT, et al. Survival in patients with primary pulmonary hypertension. Results from a national prospective study. Ann Intern Med 1991;115:343-349.

72. Hassoun PM. Therapies for scleroderma-related pulmonary arterial hypertension. Expert Rev Respir Med 2009;3:187-196.

73. Badesch DB, Tapson VF, McGoon MD, Brundage BH, Rubin LJ, Wigley FM, Rich S, Barst RJ, Barrett PS, Kral KM, et al. Continuous intravenous epoprostenol for pulmonary hypertension due to the scleroderma spectrum of disease. A randomized, controlled trial. Ann Intern Med 2000;132:425-434.

74. Denton CP, Humbert M, Rubin L, Black CM. Bosentan treatment for pulmonary arterial hypertension related to connective tissue disease: a subgroup analysis of the pivotal clinical trials and their open-label extensions. Ann Rheum Dis 2006;65:1336-1340.

75. Jain M, Varga J. Bosentan for the treatment of systemic sclerosisassociated pulmonary arterial hypertension, pulmonary fibrosis and digital ulcers. Expert Opin Pharmacother 2006;7:1487-1501.

76. Badesch DB, Hill NS, Burgess G, Rubin LJ, Barst RJ, Galie N, Simonneau G. Sildenafil for pulmonary arterial hypertension associated with connective tissue disease. J Rheumatol 2007;34:2417-2422.

77. Galie N, Brundage BH, Ghofrani HA, Oudiz RJ, Simonneau G, Safdar Z, Shapiro S, White RJ, Chan M, Beardsworth A, et al. Tadalafil 
therapy for pulmonary arterial hypertension. Circulation 2009;119: 2894-2903.

78. Mathai SC, Girgis RE, Fisher MR, Champion HC, Housten-Harris T, Zaiman A, Hassoun PM. Addition of sildenafil to bosentan monotherapy in pulmonary arterial hypertension. Eur Respir J 2007;29:469-475.

79. Schachna L, Medsger TA Jr, Dauber JH, Wigley FM, Braunstein NA, White B, Steen VD, Conte JV, Yang SC, McCurry KR, et al. Lung transplantation in scleroderma compared with idiopathic pulmonary fibrosis and idiopathic pulmonary arterial hypertension. Arthritis Rheum 2006;54:3954-3961.

80. Shitrit D, Amital A, Peled N, Raviv Y, Medalion B, Saute M, Kramer MR. Lung transplantation in patients with scleroderma: case series, review of the literature, and criteria for transplantation. Clin Transplant 2009;23:178-183.

81. Ghofrani HA, Seeger W, Grimminger F. Imatinib for the treatment of pulmonary arterial hypertension. N Engl J Med 2005;353:1412-1413.

82. Souza R, Sitbon O, Parent F, Simonneau G, Humbert M. Long term imatinib treatment in pulmonary arterial hypertension. Thorax 2006; 61:736.

83. Overbeek MJ, van Nieuw Amerongen GP, Boonstra A, Smit EF, VonkNoordegraaf A. Possible role of imatinib in clinical pulmonary venoocclusive disease. Eur Respir J 2008;32:232-235.
84. Williams MH, Das C, Handler CE, Akram MR, Davar J, Denton CP, Smith CJ, Black CM, Coghlan JG. Systemic sclerosis associated pulmonary hypertension: improved survival in the current era. Heart 2006:92:926-932.

85. Distler O, Behrens F, Pittrow D, Huscher D, Denton CP, Foeldvari I, Humbert M, Matucci-Cerinic M, Nash P, Opitz CF, et al. Defining appropriate outcome measures in pulmonary arterial hypertension related to systemic sclerosis: a Delphi consensus study with cluster analysis. Arthritis Rheum 2008;59:867-875.

86. Williams MH, Handler CE, Akram R, Smith CJ, Das C, Smee J, Nair D, Denton CP, Black CM, Coghlan JG. Role of N-terminal brain natriuretic peptide (N-TproBNP) in scleroderma-associated pulmonary arterial hypertension. Eur Heart $J$ 2006;27:1485-1494.

87. Mathai SC, Buesco M, Hummers L, Boyce D, Lechtzin N, Le Pavec J, Champion HC, Housten T, Forfia PR, Zaiman A, et al. N-terminal pro-brain natriuretic peptide is a unique marker of poor survival in scleroderma-related pulmonary arterial hypertension. Eur Respir $J$ 2010 Jan;35:95-104.

88. Bezante GP, Rollando D, Sessarego M, Panico N, Setti M, Filaci G, Molinari G, Balbi M, Cutolo M, Barsotti A, et al. Cardiac magnetic resonance imaging detects subclinical right ventricular impairment in systemic sclerosis. J Rheumatol 2007;34:2431-2437. 